\title{
The Practice of Buddhistic Austerities and Its Popularization in Shan-Tao and Prince-Shôtoku
}

\author{
—in Connection with Śrīmālā and Vaidehī-
}

\section{Haruhiko Masaki}

Viewed from the standpoint of the philosophy of sunyatā, and the fundamental premise that all sentient beings have the Buddha-nature innately (seen in the verse of Mahāparinirvāna-sūtra), there must be no discrimination between mundane existence and deliverance. If one should think there were any distinction, it would be wrong. This thought led to the conclusion in practice that the essence of religion should be sought for, not in the life of recluses, but in the lay life of householders. Laymen Buddhism, consequently, came to be advocated. It claimed to deliver more people from sufferings, than could be expected in recluses. So, this can be said a developed form of Mahāyāna Buddhism. But there seemed to be, in fact, several sūtras which are preached grounded on the life of recluses, the lay life of householders and the both of them. Furthermore, the same sūtra might leave a various impression upon the reader's mind. This trend is remarkable in the domain of practical philosophy. In the elucidation of sūtra, the contents may often look differently according to each person's subjective point of view, when we would grasp the absolute meaning apart from mere superficial philology. So, with the interpretation on it, we could say the translator's idea which based on their personal experiences of religion, contrary to the objective view of it, gets greatly mixed. It would be going too far to discuss between the right and wrong, because there may be 
the numberless Way to the perfect enlightenment or unsurpassed wisdom of the Buddhas (anuttara-samyak-sambodhi). But it is very significant that the translator's intention becomes clear by tracing the different explanation on the identical sütra to its origin. On the other hand, the subjects being quite different with each other, it is conceivably possible that the commentaries have much in common in the fundamental characters. I intend to take this problem into consideration setting limits to the exposition of "Śrīmālā-devīsiṃhānada-sūtra" and "Amitāyur-dhyāna-sūtra".

The Śrīmālā-devī-siṃhānada-sūtra (Shêng-man-ching) has fifteen chapters and it is a sermon delived by a pious princess Śrimālā, a lay woman, and it was sanctioned by the Buddha. The text exists in Tibetan and Chinese. The Sanskrit original is lost, but fragments of it are conveyed as citations in other works. (cf. "Śrīmālā-devī-sūtra and Ratnacandrapariprcchāsūtra in Tibetan, Chinese and Japanese versions" compiled by Hōdōkai. Fragments of the Text were collected and into Japanese under the title of "Studies on Hōshōron" by H. Ui.) There exist two Chinese translations. Here I quote

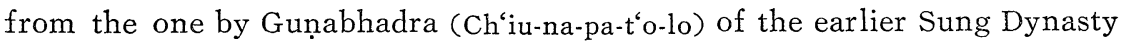
in one fascicle (vol. 12, Taishō-Shinshū-Daizōkyō, hereinafter referred to as T. S. D.), and the other by Bodhiruci ( $\left.P^{\prime} u-t^{\prime} i-l i u-c h i h\right)$ of the $T^{\prime}$ ang Dynasty, which is the forty-eighth sūtra of a collection of Mahāyāna sūtras entitled the Mahāratnakūṭa (Ta-pao-chi). This sūtra was explained by about thirteen scholars (cf. p. $242 \mathrm{~A} \sim \mathrm{B}$, the list of T. S. D. vol. 1). "Shêng-man-ching-pao-kú", a six-fascicle commentary on this sūtra by Chi-ts'ang of the Sui Dynasty (vol. 37, T. S. D) and "Shōmangyō-gisho", a one-or-three-fascicle commentary on the sūtra by Prince Shōtoku of Japan (here I used Shōwa-Ehon ed. Hōryūji) are typical. This sūtra became very important in Chinese and Japanese Buddhism.

The Amitāyur-buddha-dhyāna-sūtra (Kuan-wu-liang-shou-ching) deals less with the description of the blessed land (just like Sukhāvatī-vyūhasūtra), but devotes more space to the exhortation of meditations (dhyanna) on Amitãyus, by means of which one may reach the Pure Land (or Pure Realm); this sūtra teaches sixteen kinds of meditation as means for birth 
in that Land. It concludes by saying that even the most sinful person can attain birth there by invoking the name of Amitãyus, and became one of the three sūtras of Japanese Pure Land Buddhism. This was translated by Kälayaśas (Ching-liang-yeh-shê) of the Liu-sung Dynasty in 424 in one fascicle (vol. 12, T. S. D.). Another translation of the sūtra is said to have been, but it was already lost. This sūtra was explained by many scholars, such as Ching-ying-ssŭ-Hui-yüan of the Sui Dynasty ("Kuang-wuliang-shou-ching-i-shu" vol. 37, T. S. D.), T'ien-t'ai-ta-shih (or Chi-i) lived during the Ch'en and Sui Dynasties ("Kuang-wu-liang-shou-fu-ching-shu" vol. 37, T. S. D.), Chi-ts'ang of the Sui Dynasty ("Kuang-wu-liang-shou-ching-i-shu" vol. 37, T.S. D.), Shan-tao of the T'ang Dynasty ("Kuang-wu-liang-shou-fo-chingshu" vol. 37, T. S. D.) and other two hundred scholars. Especially Shan-tao's, a work in four fascicles, also called Ssŭ-t'ieh-su, is famous.

The versions of Prince Shōtoku and Chi-ts'ang over "Śrīmālā-devīsimphānada-sūtra", and of Shan-tao and the other three over "Amitāyurdhyāna-sūtra" just correspond to the instance of different explanation on the identical sūtra above mentioned. The views of Prince Shōtoku on Śrīmālā and of Shan-tao on Vaidehī deserve the case of common characters interpreting the quite different subjects. Therefore, I'll try the double comparison of the Prince Shōtoku's opinion on "Śrīmālā-siṃhānada-sūtra" which will be made clear by setting against Chi-ts'ang's, with Shan-tao's on "Amitãyur-dhyāna-sūtra" by contrasting with the other three's. These comparison of the view in commentaries, I think, is very effective to understand their mental attitude of Buddhistic austerities.

As a matter of common opinion-shown in its title-the "Śrīmālā-devīsimhānada-sūtra" is said to be depicting Śrīmālā as a model of what a Buddhist woman should be. But it's merely a superficial interpretation. It may safely be said that this sūtra, in fact, strongly prevails upon all women or many more persons to put the doctrine in practice, exceeding her individual issue of a matter (e.g. p. 223 A, Śrīmālä-sūtra. vol.12, T. S. D.). Prince Shōtoku, I think, had a firm belief that the Empress Śrīmālā was 
not only an ideological ideal of a lady, but a real and familiar woman with us. Details are given concretely as under;

Chi-ts'ang who takes a view that

"Women are impure and with several hindrances." (the commentary of

Chi-ts'ang, hereinafter referred to as "S. C.", p. 2 B, vol. 37, T. S. D.) advokates that it means "extremely low grade person" (do. p. 12 A B) Śrimālā's receiving the gift of life as a woman. Prince Shōtoku also accepts her

"an ignorant woman of the true nature of existence" (the commentary of

Prince Shōtoku, hereinafter referred to as "S. S.", p. 5 R. Shōwa-Ehon).

The weakness is emphasized there unanimously. However, in the preface this sūtra said

"She is the people with keen minds who are capable of understanding the subtle teaching of the Buddha." (Śrīmālā-sūtra p. 217 A, vol. 12, T.S.D.) Concerned with interpretation on this verse, there seemed to be little to choose between the two (do. p. 11 A, "S. C." / p. 4 R. "S. S."). But seeing the other page, we'll find the delicate shades of view, which are delived from the fundamental difference of her. According to Chi-ts'ang's interpretation on the other verse,

"Śrīmālā is much sagacious and competent in comparison with an ordinary person." (p.12 A, "S. C.", T. S. D.)

Prince Shōtoku does not think so.

"Though her desires are lofty and results of it are profound, she is an ignorant woman." (p. 9L., p. 14 R. "S.S.”, S. E.)

How did the difference of nuance come about? To clear up the cause, we must inquire into another explanation upon her. Namely both commentary have double version.

《Chi-ts'ang》

"She is the being of the absolute nature of the Buddha-mind which is ineffable and non-substantial, that is, the body of the highest aspect (of the threefold body) of the Buddha (dharmakäya). The reincarnation of a Buddha made His appearance as a lady to convert to Buddhism and 
teach the proper and true faith." (p. 2 B, "S. C." vol. 37. T. S. D.) "Discussing Śrīmālā's stage in daśa bhūmayah, the ten stages of developing the Buddha-wisdom,........... A certain person says 'If we judge' the stage by Daśabhūmika-sūtra (Shih-ti-ching) or this sūtra, those below seventh (dūramgama) may be physical existence in spite of proceeding far, and above eighth (acala) may be dharma-kāya for attainment of immobility.' Therefore Srīmāla must be dharma-kāya in the stage of eighth." (do. p. 3 A)

"Being already dharma-kāya, Śrīmālā appears at will......" (do. p. 4 B.): 《Prince Shōtoku》》

"Śrīmālā's nature is transcending human thought (acintya). She is marvelous and unfathomable. How should we know that she is a delivery of tathägata and the existence of dharmamegha who has the ability to spread the teachings over the dharma-dhātu as clouds overspread the sky? The reincarnation of a Buddha appeared in Ayodhya as a lady. with the sole object to teach the real and true Buddhism........." (p. 1 R. “S. S.”)

"The original nature of Srimālā is acintya, but the manifestation or reincarnation of it is in the stage of the seventh (düramgama)." (do. p. 5 L.) These quotations show their fundamental attitude toward Śrīmālā. By the understanding of Prince Shōtoku, she must be taken for a real or physical woman especially in this sūtra, but her original nature is a delivery of tathägata and she is the existence of dharmamegha. What is more on another passage (cf. p. 13 R. "S. S.", S. E.), he grades her in the rank of the seventh bodhisattva who are far from perfect to accept and practice the righteous law. After all, this sūtra is the Śrīmālā's sermon from the seventhstage standpoint.

Chi-ts'ang, on the other hand, regards her original nature as dharmakāya just like Shōtoku. But opinion is divided on the rank of manifestation. He decides it as dharma-kāya (above eighth) too based on "Daśabhūmika-sūtra". So this interpretation forms a striking contrast to that. This may be a sensible interpretation of the sūtra. But Prince Shōtoku does not 
think so. If we regarded her manifestation also as dharma-kāya just like her original nature, she would become distantly related to us, and there would be little reason why the reincarnation of a Buddha should have appeared in Ayodhyā as a lady. According to the "S. S.", she appeared with the sole object to teach the real and true Buddhism. This appearance does not mean an abstruct idea, but real and historical being. This version brought about better results of familiarity to readers. By the opinion of Prince Shōtoku, the object of salvation will be much enralged toward the whole suffering beings.

Prince Shōtoku makes a clear distinction between the stage of the seventh (dūramgama) and the eighth (acala). (p. 13 R., p. 15 R. L., p. 24 L., p. 25 R., p. 28 R., p. 30 R. L. cf. pp. 18 L. $\sim 19$ R., pp. 20 L. 22 L., pp. 22 L. 23 R., p. 36 L., p. 37 R., pp. 55 L. $\sim 56$ R., p. 56 R. L., p. 69 L. "S. S." S. E.) Though Prince Shōtoku appreciated real worth of religious acts or exercises (in Mahâyāna) aimed at taking one closer to the final goal of enlightenment, in the stages above eighth, he took Śrimālā's rank for seventh while Chi-ts'ang eighth. He gave, I think, much more weight to exhorting easy practice than of high degree or the difficult way to enlightenment. The delicate shades of view which is seen in the interpretation on her has been derived from those fundamental difference between them.

Prince Shōtoku has a lofty ideal of Buddhistic aim, seen in the valuation of the eighth (cf. p. 14 L. "S. S.", S. E.). Chi-ts'ang is very much the same as him. Notwithstanding the preceding appraisal, Prince Shōtoku, on the other paragraphs, accepts her

"an ignorant woman of the true nature of existence". (p. 5 R., "S. S." S. E.) In 593, he prevailed upon his father, the Emperor, to issue an Imperial Message suporting Buddhism. In 594, when the Korean monk Eji came to Japan, he studied under him. He professed the Buddhist faith as a layman. He interpreted "Shêng-man-ching" with intend to show the proper attitude in Buddhistic austerities. That is not to keep the purpose too high to attain, but from a layman's standpoint to be awakened to our facts of ignorant beings (prthag-jana), just emphasized in the "Constitution of 
Seventeen Chapters" promulgated by him in 604. In due consideration of the ability in prthag-jana, it is much more fundamental than mastery of the Buddhistic doctrines which are difficult to understand, to practise Good (kusala) which is one of the three moral natures (cf. pp. 29 R. 30 L. "S. S.", S. E.). Though there are wide difference of excellent and poor in the ability of understanding, the practical observance of the Buddha's teaching is always workable. And "Good" he says may be even a single invoking the name of Amitābha-buddha or Amitāyur-buddha vocally (śabda-vidya), and meditating upon him (Buddhänusmrti). Far from that, Prince Shōtoku must have thought just a single invoking indeed the most simple and supreme practice in Buddhism. His interpretation on. Śrīmālā must be originated in his own severe ascetic exercises and reflection of prthag-jana. I can not but conclude that his commentary on the Śrimanlā-devī-simhannada-sūtra is the project of his actuality in studying Buddhism, and the unique view of Śrīmālä is brought about as a natural cause of event.

"Amitāyur-dhyāna-sūtra" (Kuan-wu-liang-shou-ching) literally means the sūtra which exhorts meditations (dhyāna) on the Absolute (Amitāyus), by means of which one may reach the Pure Land of the Highest Joy (Sukhāvatī). In the Buddhāvatamsaka-sūtra the Pure Land of Amitābhā was regarded as the most inferior one among many pure lands, which are nearest to the defiled and mundane world (sahā). It means that it was the thought most accessible to common people. The tendency to suppose the existence of a happier land in the western direction is a religious belief which can be noticed among primitive tribes, and Pure Land Buddhism must have shared it. So it is likely that early Pure, Land Buddhism appeared from among the orders of laymen. There remain a large number of commentaries on this sūtra. It is supposed that many passages were inserted on purpose, by explanators' arbitrary decision. Especially, there are tremendous discrepancies between the Shan-tao's and the others'. I'll give a few concrete examples and sound out Shan-tao's intention which can be read between the lines. 
Shan-tao has been described as the severe and well trained scholar who could attain to the enlightenment by his own efforts, by means of several biographical writings. (e.g. "Hsü-kao-sêng-ch'uan"; A thirty fascicle collection of biographies of famous priests, compiled by Tao-hsüan of the T'ang Dynasty. No. 27, p. 684 A, vol. 50, T. S. D. / "Fo-tsu-t"ung-chi"; A fifty-four fascicle work written by the Sung Dynasty priest Chih-p'an. No. 26, 27. p. $263 \mathrm{~A} \sim$ B, p. 276 B, vol. 49. T. S. D. et al.) But his attitude in commenting upon this sutra is far removed from his personal practice, just like Holy path which leads to salvation through self-help. At first, concerning the essence of this sūtra, I'll show a few lines quoted from the explanation by Shan-tao and other three scholars.

《Ching-ying-ssŭ-Hui-yüan》

"Speaking of the main meaning of the sūtra, …........this sūtra has a purpose to urge strongly the meditation on Buddha (Buddhānusmrti). ............Here is the sufficient reason why this sutra was named "Amitāyur-dhyāna (meditation) -sūtra". (p. $173 \mathrm{~A} \sim \mathrm{C}$, vol. 37. T. S. D.)

《T'ien-t'ai-ta-shih (or $C h i-i)\rangle$

"This sūtra aims at encouraging all sentient beings to meditate on Buddha and to know the universal and eternal truth applicable to all things (The Tathatā)." (p. 186 C. vol. 37, T. S. D.)

"The purpose of this sūtra is to observe the pureness of that Land by mind." (do. p. 188 B. cf. p. 188 C)

《Chi-ts'ang》

"The essence of this sūtra is to give encouragement all beings to meditate Buddha as rüpa-kāya which has mass and therefore can obstruct." (p. 234 C. cf. p. 238 B. vol. 37, T. S. D.)

《Shan-tao》

"This sūtra is urging all sentient beings to meditate on Buddha (Buddhanusmrti) and to invoke the name of Buddha." (p. 247 A. vol. 37, T. S. D.) Shown in quotations, the essence of this sūtra emphasized by the three scholars (Hui-yüan, Chi-i and Chi-ts'ang) is just the "meditation upon Amitābha Buddha", which was the essential practice throughout all Pure Land 
Scriptures of India and the greater part of Chinese commentaries with a few exception. Though in the sũtra we can find the verse "invoking the name of Amitābha Buddha vocally", these three scholars who considered the exercises taught in this sütra was too high for common people, took no account of it and regarded Buddhānusmrti as a practice for superior one. Shan-tao, contrary to them, establishes a sharp distinction between "meditation on Buddha" and "invoking the name of Buddha". Accordingly, he founded externally two meanings in it as decribed above. But in the other passages, it seemed to be advocated a different idea.

"This sūtra teaches that anyone who merely chants the name of Amitāyus and thinks of it, will be born in the blessed land (upapadyate)." (p. 268 A, vol. 37. T. S. D.)

"The virtue of invoking the name of Buddha has marvelous property and cannot bear comparison with other practice.......... Buddha is said to have made forty-eight vows to save living beings from sufferings. From this point of view his real aim may be to make all sentient beings invoke the name of Buddha, while there mentioned two ways of practice." (p. 278 A. vol. 37. T. S. D.)

Shan-tao interpreted the word "Buddhānusmṛti" as meaning "invocation to Amitābha-Buddha by repeating his name." It is from the time of T'anluan onward, I think, that this term referred to this meaning. Furthermore in Shan-tao invocation of the Name meant the definite formula "namuamida-butsu" in Japanese (putting one's faith in Amitābha Buddha) in order to be reborn in his Pure Land, and since then this interpretation has been subscribed to by most Chinese and Japanese Pure Land Buddhists. The difference between Shan-tao and the other three scholar concerning the essence of this sūtra, naturally follows another discrepancy of the meaning on Buddhānusmṛti. This should literally means the meditation on Buddha, widely said, on the Pure Realm, the distinguishing marks on the rūpa-kāya of the Buddha (thirty-two lakṣanas and eighty vyañjanas). (Hui-yüan; p. $180 \mathrm{C}$. vol. 37. T. S. D. / Chi'ts'ang; p. 242 C, cf. p. 238 B. vol. 37, T. S. D. / cf. Chi-i; p. 194 B. vol. 37. T. S. D.) This interpretation is quite natural. Shan-tao, without 
reference to the verse of the sūtra, ventures to say that Buddhānusmṛti means just the invocation to him by repeating his name, which is the easiest practice to all beings.

Next, let's consult their commentaries touching upon the nature of Vaidehī.

"The original deity of Vaidehĩ is, in fact, bodhisattva, who practices the teaching of Buddhism in both other-worldly and secular ways of life." (Hui-yüan; p. 179 A, vol. 37. T. S. D. / Chi-i ; p. 191 B, vol. 37. T. S. D.) 《Shan-tao》

"She is not a saint, but an ignorant woman of suffering (pṛthag-jana)." (p. 260 C. vol. 37. T. S. D.).

Moreover he added;

"She must ask call for the help of Buddha, because of not being a saint." (cf. p. 257 C, p. 260 C. vol. 37. T. S. D.)

If we judged the nature of Vaidehi extremely high grade shown in the explanations of the three, it would come to an unnatural result that the bodhisattva who will vow to save all beings and work with compassion for suffering beings instead of becoming a Buddha immediately, prays to the Absolute for saving, and the teaching of this sütra would become estranged from suffering mortals and the all-embracing, compassionate character of Amitäbha would also become less appealing to the feeble existence. This difference between them arises new differences on the evaluation of anutpattika-dharma-kșanti that is the stage attained by a bodhisattva in which he perceives the dharmatā.

《Hui-yüan and Chi-i》》

"By the prajñāpāramitā-sūtra, this stage is attained by bodhisattvas of the seventh, eighth, and ninth bhumi in the ten stages of developing the Buddha-wisdom (daśa-bhūmayah)." (Hui-yüan; p. 179 A, vol. 37. T. S. D. /Chi-i; p. 191 B, vol. 37. T. S. D.) 《Chi-ts'ang》

"......this must be anutpattika-dharma-kșanti of the seventh bhumi." (p. 244 C, vol. 37. T. S. D.) 
《Shan-tao》》

"It refers to a person who is sure that he will be reborn in the Pure Land. It is one of the fifty-two bodhisattva stages, namely the ten stages of faith, security, practice, devotion, development, a stage of approaching Buddhahood, and a stage of Buddhahood." (p. $260 \mathrm{C}$, vol. 37. T. S. D.)

The same discrimination is seen concerning the time when she became awakened and gained anutpattika-dharma-kṣanti in Buddha's sermon of this sūtra. (Hui-yüan; p. 186 A, / cf. Chi-i; p. 194 B, / Chi-ts'ang; p. 245 B. / Shantao; p. 251 B. vol. 37. T. S. D.) These opinions of Shan-tao divided on each point, are no more than a chain of his intention; he tried this sūtra to be intimate with us by regarding it as "the persuading-to-invoke-the-nameof-Buddha-sūtra."

The name Amitābha (Limitless Splendor) was translated in Chinese versions as the "Limitless Life", because the latter name was more popular and welcome among Chinese who subscribed to the Taoistic theory of longevity. And the practice of Buddhānusmrti, which originally meant "Meditation on Buddha" was transformed after Shan-tao to that of invocation by mouth, because of to the trend among the Chinese to esteem magical power. Shan-tao has firm belief that the salvation by invocation is never inferior to that of other practices such as meditation, but this salvation was just the real and original purpose of Buddha. So, he emphasizes, it is for prthag-jana that the teachings of "Amitāyur-dhyāna-sūtra" was shown, through the medium of Vaideh $\overline{1}$ who was intimate with us. In the first chapter of his commentary, he verifies this theory taking ten verses from the sūtra as an example (p. $249 \mathrm{~B} \sim$ C, vol. 37. T. S. D.), while it goes without saying that the translations of them (the three) closely follow the contents of original sūtra. It is very significant that his translating attitude on the sūtra stands out in sharp contrast to his personal exercise. It ought not to be mere "two faces" of a man, but these two are seemed to stand on the common basis; the more severely he had reflected on himself, on the contrary, the more easily he intepreted the sūtra. 
I've surveyed some distinguishing traits in the versions of Prince Shōtoku and Chi-ts'ang over "Śrīmālā-sūtra", and of Shan-tao and other three over "Amitāyur-dhyāna-sūtra". I've also criticized on the meaning that the view of Prince Shōtoku on Śrīmālā and of Shan-tao on Vaidehī have much in common in the fundamental characters, interpreting quite different sūtra. A harmony between the ideal and reality is shown in common in the com. munity of their thought. Though Prince Shōtoku has the lofty ideal of Buddhistic aim, but he'll not require us to reduce a doctrine to practice beyond our power. His real intention may be not only to keep the goal too high to attain, but to pursue the realizable way to all laymen. It is for this purpose that he took good care to grasp the meaning of the sūtra plainly and to extend possibility of practice to all prthag-jana, while the extraordinary volition may be gathered from his view of the eighth stage or dharma-kāya. There would be no need to draw a forced inference, if he regarded her rank of manifestation as eighth stage (dharma-kāya) just like Chi-ts'ang. So with the Shan-tao's explanation on Vaidehī, if he regarded her not being a prthag-jana. We can find the remarkable similarity between the most simple and supreme practice in Shōtoku (a single invoking the name of Amitābha-buddha or Amitāyur-buddha vocally and meditation upon him) and the explanation of Shan-tao that the most evil man who belongs to the lowest grade of the lowest life (the last of the nine kinds of life mentioned in the Kuan-wu-liang-shou-ching) can be born in the Pure Land of Amitābha by a single invoking the name of Amitäbha-buddha on his death bed (p. $277 \mathrm{~B} \sim$ C, vol. 37. T. S. D.). If they interpreted these sūtras otherwise, Śrīmālā-sūtra and its heroine would become disconnected with our reality, and Kuan-wu-liang-shou-ching would also become considered the difficult sūtra to realize which forced us to meditate upon Amitābha-buddha in several ways. If that is the case, it would be far from saving all sentient being in future. Shan-tao and Prince-Shōtoku must intend to open the door to pṛthag-jana by regarding them (Śrīmālā and Vaidehī) as real and ignorant woman.

Thinking of the reason why these opinions should come out, it must 
be a natural effect of the self-consciousness of prthag-jana in Prince Shōtoku and of severe training and self-reflection of pṛthag-jana in Shantao, as mentioned above. Then the word "populace" does not only mean any other person, but also it may include himself or to say more exactly, just himself and none other. (The fact that in later days Prince Shōtoku called himself "The Śrīmālā, the son of the Buddha" as a Buddhist name, is closely connected with his translating on Vaidehi close to himself.) A harmony between the ideal and reality may be, say in other words, the emphasis of practice. Presupposing the possibility of practice for all person, they would be able to convince us of their characteristic or unique commentary exceeding mere literal sense. This signifies their subjecthood derived from the wide gazing at the realities of life and deep experience on religion, and the fact that their thought has made a great impression on our mind, may have been proving the universality of their fundamental attitudes. I think this is an expression of the popularization of Buddhistic exercises in Shan-tao and Prince Shōtoku. 